\title{
Attitude of Extension Field Functionaries towards Agriculture Technology Management Agency in Southern Karnataka
}

\author{
S. Shamshadunnisa*, G.M. Varadaraju, Mohd Riyaz and Tanweer Ahmed \\ Department of Agricultural Extension, College of Agriculture, UAS, GKVK, Bengaluru- \\ 560065, India \\ *Corresponding author
}

\begin{tabular}{|l|}
\hline K e y w o r d s \\
Attitude, Extension \\
field functionaries, \\
ATMA
\end{tabular}

\section{A B S T R A C T}

Agriculture Technology Management Agency (ATMA) is a registered society which involves key stakeholders to perform agriculture activities for sustainable agricultural development at district level.

ATMA is having linkage with all the line departments, research institutions, Non-Governmental Organizations and agencies associated with agriculture development in the district. The study was carried out during 2016-17 in six southern districts of Karnataka state to analyze the attitude of extension field functionaries towards ATMA. The total sample constituted 90 extension field functionaries from the selected districts namely Bengaluru Rural, Bengaluru Urban, Chickaballapura, Kolar, Tumakuru and Ramanagara. Ex post facto research design was employed for the study. Data were collected from the respondents using structured interview schedule. Attitude was measured using a scale consisting of 14 statements related to ATMA. Appropriate statistical tools like frequency, percentage, mean, standard deviation were used for analysis of data. The results revealed that about 36.67 per cent of the extension field functionaries had more favourable attitude towards ATMA, while 35.33 per cent of them had least favourable attitude and the remaining 27.78 per cent of them had favourable attitude towards ATMA.

\section{Introduction}

Agriculture is the backbone of Indian economy, about 66.67 per cent of its population depends directly or indirectly on it. Since agriculture production is entirely in the hands of the farmers, the extension services becomes the central role in informing, motivating and educating the farmers about the available technologies which enables them to improve their farm productivity and net income. Hence the central government initiated a scheme called Support to State Extension Programmes for Extension Reforms (SSEPER) during 2005-06 which aims at making the extension system farmer driven and farmer accountable by way of new institutional arrangement for technology dissemination in the form of Agriculture Technology Management Agency (ATMA). ATMA is a registered society which involves key stakeholders to perform agriculture activities for sustainable agricultural development at district level. It is defined as a 
semi-autonomous decentralized participatory and market-driven extension model which helps in technology dissemination of major crops towards diversifying output. It is a focal point for integrating research and extension activities and decentralizing day to day management of public Agricultural Technological System (ATS). ATMA is having linkage with all the line departments, research institutions, Non-Governmental Organizations and agencies associated with agriculture development in the district. In ATMA model, local research and extension priorities are set up through Strategic Research and Extension Plans (SREP) which are developed through Participatory Rural Appraisal (PRA) techniques with full participation of farmers, technical officers of agriculture and allied department as well as from KVKs and other research institutions. SREP is a comprehensive agricultural plan document prepared by participatory method for integrated development of the district. Its purpose is to identify research and extension needs of the district. SREP is the back bone of ATMA and its preparation and implementation is necessary for the success of ATMA approach. Attitude of extension field functionaries i.e., Assistant Technology Managers towards ATMA plays an important role transfer of technology to the farming community. In this backdrop, it was felt important to assess the attitude of extension field functionaries towards ATMA and to study the relationship between personal, psychological and socio-economic characteristics of extension field functionaries with their attitude towards ATMA.

\section{Materials and Methods}

The present study was undertaken in Bengaluru Rural, Bengaluru Urban, Chickaballapura, Kolar, Tumakuru and Ramanagara districts of Karnataka state during 2016-17. Research design used for the study was ex-post facto technique. Based on the available strength of extension field functionaries in above six selected districts, 30 extension field functionaries from Tumakuru, 19 from Chikkaballapura, 18 from Kolar, 12 from Ramanagara, 8 from Bengaluru Rural and 3 from Bengaluru Urban were selected thus the total sample size constitutes of 90 respondents. The data were collected with the help of pre tested structured interview schedule through personal interview method.

Attitude is the degree of positive or negative feeling towards persons, phrases, slogans, symbols, institutions or ideas towards which people can differ in varying degrees from point of view of social psychology (Thurstone, 1946). It is the preparedness of people to respond in a certain way towards social object or phenomena. Further, the attitude towards ATMA was operationalized as individuals degree of favourableness or unfavourableness towards ATMA. The respondent's attitude was measured using the procedure adopted by Nisha Chouhan (2013).

Information on personal, socio-economic and psychological characteristics (independent variables) of extension field functionaries were collected using a structured schedule with suitable scales. The data collected was scored, tabulated and analyzed using frequency, mean, standard deviation, correlation and multiple regression analysis.

\section{Results and Discussion}

Table 1 depicts that among the fourteen statements related to ATMA, ATMA is a well structured programme compared to any other programme, obtained a highest mean score of 4.06 and was accorded the first rank by the extension field functionaries. The statement ATMA creates positive impact on agricultural development in Karnataka, received a score of 4.04 and was ranked second. The statement 
'ATMA does good job for improving the livelihood status of farmers' obtained a mean attitude score of 3.98 and was ranked third by the extension field functionaries. 'ATMA enhances overall efficiency of agricultural production system' was ranked fourth with a mean attitude score of 3.91. The statement ' Required funds are released timely under ATMA' received a mean attitude score of 3.88 and was ranked fifth. 'ATMA is more focusing on resource poor farmers' obtained a mean attitude score of 3.57 and was ranked sixth. The statement 'ATMA provides proper trainings to staff in various aspects using Participatory Rural Appraisal technique and team building etc.' was received a mean attitude score of 3.46 and was ranked seventh. 'Participation of NGOs is up to expected level' was obtained a mean score of 3.41 and was ranked eighth. The negative statement 'Functions and roles of various line departments in the districts are not mentioned under ATMA' obtained a mean attitude score of 3.40 and was ranked ninth. The statement
'ATMA provides operational skill development programmes to the extension field functionaries' received a mean attitude score of 3.36 and was ranked tenth. The remaining four statements, namely, 'ATMA helps to build confidence in farmers', 'Participation of small and marginal farmers is low in various farmers organizations in ATMA', 'There is no awareness among farmers about the concept of ATMA programme so their participation is low' and 'There is proper co-ordination among line departments' were ranked eleventh, twelfth, thirteenth and fourteenth with mean attitude scores of 3.35, 3.01, 2.82 and 2.84 respectively (Fig. 1).

The findings indicated that the extension field functionaries have favourable attitude towards various aspects of ATMA. It evidently proves that ATMA model is very beneficial to the extension field functionaries for updating agricultural information and dissemination of the same to the farming community.

Fig.1 Overall attitude of extension field functionaries towards ATMA

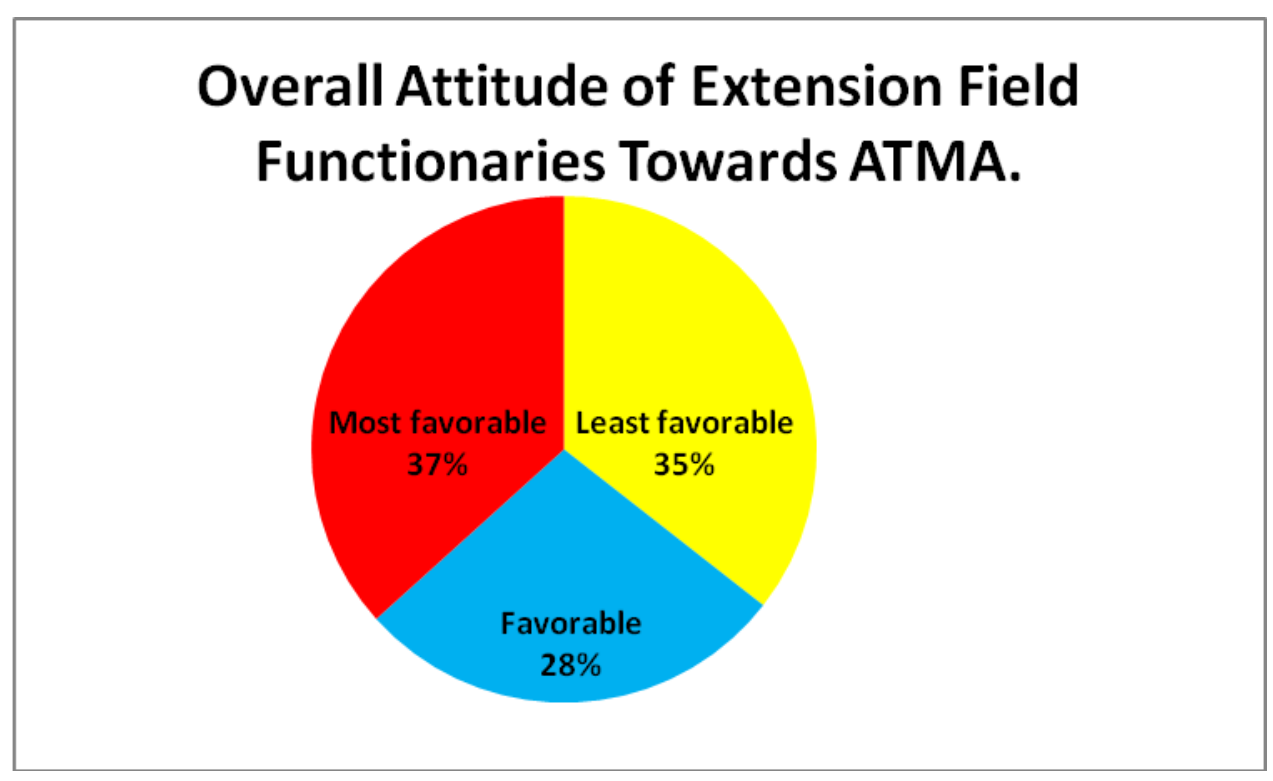


Table.1 Statement-wise attitude of extension field functionaries towards ATMA

$(\mathbf{n}=90)$

\begin{tabular}{|c|c|c|}
\hline \multirow[t]{2}{*}{ Attitude statements } & \multicolumn{2}{|c|}{ Extension field functionaries } \\
\hline & $\begin{array}{l}\text { Mean attitude } \\
\text { score }\end{array}$ & Rank \\
\hline ATMA is a well structured programme compared to any other programme & 4.06 & I \\
\hline ATMA creates positive impact on agricultural development in Karnataka & 4.04 & II \\
\hline ATMA does good job for improving the livelihood status of farmers & 3.98 & III \\
\hline ATMA enhances overall efficiency of agricultural production system & 3.91 & IV \\
\hline $\begin{array}{l}\text { Required funds are released timely under A } \\
\text { TMA }\end{array}$ & 3.88 & $\mathrm{~V}$ \\
\hline ATMA is more focusing on resource poor farmers & 3.57 & VI \\
\hline $\begin{array}{l}\text { ATMA provides proper trainings to staff in various aspects using } \\
\text { Participatory Rural Appraisal technique and team building etc. }\end{array}$ & 3.46 & VII \\
\hline Participation of NGOs is up to expected level & 3.41 & VIII \\
\hline $\begin{array}{l}\text { Functions and roles of various line departments in the districts are not } \\
\text { mentioned under ATMA* }\end{array}$ & 3.40 & IX \\
\hline $\begin{array}{l}\text { ATMA provides operational skill development programmes to the } \\
\text { extension field functionaries. }\end{array}$ & 3.36 & $\mathrm{X}$ \\
\hline ATMA helps to build confidence in farmers & 3.35 & XI \\
\hline $\begin{array}{l}\text { Participation of small and marginal farmers is low in various farmers } \\
\text { organizations in ATMA. }\end{array}$ & 3.01 & XII \\
\hline $\begin{array}{l}\text { There is no awareness among farmers about the concept of ATMA } \\
\text { programme so their participation is low }\end{array}$ & 2.84 & XIII \\
\hline There is proper co-ordination among line departments & 2.82 & XIV \\
\hline
\end{tabular}

* Negative statement

Table.2 Overall attitude of extension field functionaries towards ATMA

$(\mathbf{n}=90)$

\begin{tabular}{|l|l|c|c|c|c|}
\hline Category & Criteria & Frequency & Per cent & Mean & SD \\
\hline $\begin{array}{l}\text { Least } \\
\text { favorable }\end{array}$ & Up to 46.56 score & 32 & 35.55 & & \\
\hline Favorable & Between $46.56-50.54$ & 25 & 27.78 & 48.55 & 3.97 \\
\hline Most favorable & More than 50.54 & 33 & 36.67 & & \\
\hline Total & & $\mathbf{9 0}$ & $\mathbf{1 0 0 . 0 0}$ & & \\
\hline
\end{tabular}

Overall attitude of extension field functionaries towards ATMA

The results in Table 2 reveals that about 36.67 per cent of the extension field functionaries had more favourable attitude towards ATMA, While 35.55 per cent of them had least favourable attitude and the remaining 27.78 per cent of them had favourable attitude towards ATMA. It can be concluded that a majority $(64.45 \%)$ of the extension field functionaries had more favourable to favourable attitude towards ATMA. 
The possible reason for this trend of finding might be due to education level of the extension field functionaries and also most of the respondents belong to young age category. Another reason might be the activities in SREP document became the generating force of enthusiasm and interest for the extension field functionaries for over all development of the district. The findings are in agreement with the findings of Verma and Lal (2008).

The above trend of findings concludes that there is low level of participation by small and marginal farmers in ATMA, even farmers are not aware about ATMA and there is no proper co ordination among line departments. Hence the concerned agencies need to draw out appropriate strategies to create awareness among the farmers about ATMA, create congenial conditions to ensure the participation of small and marginal farmers. Also there is a need of strong institutional linkage mechanism to ensure the co ordination between all the line departments so that actual vision and objectives of ATMA can be achieved which in turn leads to the betterment of farming community.

\section{References}

Ankaiah Kumar K. 2009, A critical analysis of co-coordination process in ATMA and its impact on stakeholders in Chittoor district of Andhra Pradesh
Ph.D. Thesis (Unpub.), Univ. Agric. Sci., Bangalore.

Babu, A. and Premalatha Singh, 2000, Attitude of Agricultural officers towards People Plan Programme. Indian. J. Extn. Edn., 35 (3\&4): 148-152.

Hashemi, Z. H., rad, G. P. and Chizari, M., 2014, Factors influencing the use of and attitude of using Information and Communication Technologies (ICTs) in agricultural extension, a study in the Isfahan province of Iran, International J. Agric. Mgt. Dev., 4(1), 51-60.

Nisha Chouhan., 2013, Constraints faced by the Farmers in getting Agricultural Technology Information under ATMA in Bikaner District of Rajasthan. M.Sc. Thesis., Rajasthan Agriculture University, Bikaner, campus- Jobner.

Saini, H. 2005. Knowledge and attitude of farmers towards vermin technology in Jaipur district of Rajasthan. M.Sc. (Ag.) Thesis, Rajasthan Agricultural University, Bikaner, Campus- Jobner.

Thrustone, L. L., 1946, The measurement of attitude. American J. Sociology, Chicago University: 39-50.

Verma, H. L. and Lal, H. 2008. Knowledge and attitude of rural youth towards programme of Nehru Yuva Kendra (NYK), Jaipur district of Rajasthan. M.Sc. Thesis., Rajasthan Agriculture University, Bikaner, campus- Jobner.

\section{How to cite this article:}

Shamshadunnisa, S., G.M. Varadaraju, Mohd Riyaz and Tanweer Ahmed. 2018. Attitude of Extension Field Functionaries towards Agriculture Technology Management Agency in Southern Karnataka. Int.J.Curr.Microbiol.App.Sci. 7(11): 2547-2551. doi: https://doi.org/10.20546/ijcmas.2018.711.289 